\title{
Pathological Mechanisms Underlying Myalgic Encephalomyelitis/Chronic Fatigue Syndrome
}

\author{
Daniel Missailidis, Sarah J. Annesley $(\mathbb{D}$ and Paul R. Fisher *(1) \\ Department of Physiology Anatomy and Microbiology, La Trobe University, VIC 3086, Australia \\ * Correspondence: P.Fisher@latrobe.edu.au; Tel.: +61-4-3756-8771
}

Received: 18 June 2019; Accepted: 19 July 2019; Published: 20 July 2019

\begin{abstract}
The underlying molecular basis of myalgic encephalomyelitis/chronic fatigue syndrome (ME/CFS) is not well understood. Characterized by chronic, unexplained fatigue, a disabling payback following exertion ("post-exertional malaise"), and variably presenting multi-system symptoms, $\mathrm{ME} / \mathrm{CFS}$ is a complex disease, which demands a concerted biomedical investigation from disparate fields of expertise. ME/CFS research and patient treatment have been challenged by the lack of diagnostic biomarkers and finding these is a prominent direction of current work. Despite these challenges, modern research demonstrates a tangible biomedical basis for the disorder across many body systems. This evidence is mostly comprised of disturbances to immunological and inflammatory pathways, autonomic and neurological dysfunction, abnormalities in muscle and mitochondrial function, shifts in metabolism, and gut physiology or gut microbiota disturbances. It is possible that these threads are together entangled as parts of an underlying molecular pathology reflecting a far-reaching homeostatic shift. Due to the variability of non-overlapping symptom presentation or precipitating events, such as infection or other bodily stresses, the initiation of body-wide pathological cascades with similar outcomes stemming from different causes may be implicated in the condition. Patient stratification to account for this heterogeneity is therefore one important consideration during exploration of potential diagnostic developments.
\end{abstract}

Keywords: myalgic encephalomyelitis; chronic fatigue syndrome; ME/CFS; diagnosis; metabolism; mitochondria; inflammation; immune system; signaling; gut microbiota

\section{Introduction}

Myalgic encephalomyelitis/chronic fatigue syndrome (ME/CFS) encompasses diverse symptoms that manifest variably across a range of body systems, the characteristic symptoms being chronic unexplained fatigue (lasting more than 6 months) and post-exertional malaise (PEM) — a disabling and exacerbated disease state following bouts of physical or mental exertion that exceed a patient-specific threshold. ME/CFS also entails a varied kaleidoscope of other symptoms including muscle weakness, migraine, flu-like symptoms, cognitive impairment ("brain fog"), and sensitivities to a variety of external stimuli that may include light, sound, or specific odors. This can be accompanied by comorbidities, such as fibromyalgia, postural orthostatic tachycardia (POTS), and Ehlers-Danlos syndrome.

A major challenge for this field of study has been the varied usage of multiple diagnostic case criteria that may render comparison between studies difficult depending on the composition of the participant cohort. Furthermore, these criteria are slow processes of exclusion that leave patients without the support or acknowledgment that they need for extended periods and they may be subjected to a protracted, harsh, and insensitive diagnostic gauntlet. These problems are further compounded by medical guidelines in some developed countries that are out of date regarding ME/CFS clinical practice and require urgent overdue revision. 
Case definitions, such as the commonly termed Oxford [1] or Fukuda [2] criteria, are most often utilized throughout the UK and USA, respectively, yet may fail to discriminate between generalized chronic fatigue and ME/CFS which specifically also involves PEM, which aids in characterizing this disorder as a discrete clinical entity. Also in usage are the Canadian Consensus Criteria [3] and International Consensus Criteria [4], which mandate PEM for a diagnosis of ME/CFS and therefore may be considered more specific definitions. While the presence of PEM is an optional component of the Fukuda criteria, PEM is, unfortunately, not required for research participation by all studies using this or other less strict definitions. Consequently, the discovery of a reliable diagnostic biomarker is perhaps the most common recurring theme in modern ME/CFS research. Despite myriad relevant study outcomes [5-16], no such discovery has yet been widely validated or implemented as a suitable diagnostic biomarker of ME/CFS.

Not only does ME/CFS affect multiple body systems and organs, but it does so with different and time-varying levels of severity and different patterns of comorbidities in different individuals, thereby producing a highly heterogeneous patient population [7,17-23]. This complexity represents a major challenge to the task of incriminating one underlying pathological mechanism. It is also possible that different causative molecular insults result in different subsequent clinical presentations and this could contribute towards heterogeneity in the disorder. Patient subtyping to manage this heterogeneity has been previously discussed in the field $[20,23]$ and is lent credence by reproduced patterns of differential disease-associated gene expression [24-26], gene expression profiles concurrent with comorbid POTS [27], distinct DNA methylation profiles associated with quality of life scores and PEM [28], severity and frequency of physical or mental fatigue [29], or irritable bowel syndrome (IBS) comorbidity [30], which can be concurrent with specific changes to patient metabolism [31]. As timely, objective, and accurate diagnosis remains the most clear challenge facing the field, patient subtyping may be an important component of new diagnostic techniques and has seen early investigation with stratification-based severity scores [32] or cytokine co-expression patterns [33].

In summation, ME/CFS etiology has been difficult to pin down due to the combination of a diagnostic quagmire and the disorder's heterogeneous symptom presentation across multiple body systems. A traditional view has held that ME/CFS onset is often precipitated by some manner of bodily insult, commonly infection, however, the disorder is left without any known single causative pathogen to date. Given the heterogeneity of the patient population, this is unsurprising. It is possible that the initial pathological insult may not always be pathogen-mediated and could instead be instigated by alternative stresses of sufficient magnitude as to nudge homeostatic regulation loops into alternative stable states [34], and these varying modes of initial insult may contribute to the heterogeneity of ME/CFS clinical presentation.

Current research shows a tangible biomedical foundation underlying this clinical puzzle. Most of this evidence pertains to disturbed muscle function, metabolism, mitochondria, immunity, signaling, neurological, adrenal, and gut health. It is possible that these threads are together entangled as parts of an underlying molecular pathology reflecting a far-reaching homeostatic shift influencing each of these systems, perhaps differentially between individuals with varying clinical features. Furthermore, evidence of abnormalities affecting multiple systems is based on associations and the causal mechanisms responsible for the underlying pathology have yet to be determined. The following sections will address the current evidence for dysfunction across these systems in ME/CFS with specific examples of potential pathological interactions.

\section{Abnormal Metabolism and Mitochondrial Function}

The nature of the persistent fatigue and PEM experienced by patients renders the area of cellular energetics fertile ground for investigation. However, in the intervening years since early studies [35-37], mitochondria had been largely neglected in the field until their re-emergence as an area of interest during the last 10 years [9]. The recent interest in this area has since generated a basis to support some manner of both mitochondrial and broader metabolic dysfunction in ME/CFS. 


\subsection{Dysregulated Amino Acid Metabolism and Impaired Provision of TCA Cycle Substrate}

This accumulation of evidence supporting dysregulated metabolism and mitochondrial energetics in ME/CFS has taken place across many experimental areas. There have been recent studies utilizing the metabolomics approach, which captures a quantitative snapshot of steady-state metabolite levels in a sample to infer underlying biochemical pathway modulation, typically achieved by either mass spectrometry (MS) or nuclear magnetic resonance (NMR) spectroscopy applications. The first of these studies used NMR to interrogate analytes within ME/CFS blood samples and reported decreases in glutamine and ornithine concentrations, suggesting abnormal amino acid metabolism linked to urea cycle dysregulation [38]. A subsequent study utilizing MS conversely reported an elevation in ornithine concentration with a decrease in citrulline, but this also suggests urea cycle dysregulation [6].

Subsequent work undertaken by the authors of the first study proposed that impaired glycolytic formation of pyruvate could be providing less downstream oxidized pyruvate derivatives to be used as substrate for the tricarboxylic acid (TCA) cycle [39]. Work by others suggested that instead of a reduction in the glycolytic pyruvate supply, a deficiency in pyruvate dehydrogenase (PDH) function may form a bottleneck for the provision of TCA cycle substrate [40]. These and the previous amino acid discrepancies could be due to differences in techniques (NMR vs. MS) and thus the range of detectable molecules. What could be taken from both lines of approach-supported by data from other similar studies $[6,13,31]$ and one cell culture study $[41]$ —is that there may be some manner of TCA cycle disturbance in ME/CFS, possibly one that is substrate supply-driven.

\subsection{Inefficient ATP Synthesis and Abnormal Energy Stress Signaling}

If the TCA cycle output of oxidative phosphorylation (OXPHOS) complex substrates is reduced by such a glycolysis [39] or PDH [40] defect, one might expect disturbances in cellular energy production in ME/CFS cells. There have been several studies which report a reduction of steady-state ATP levels [9,42,43], yet other studies have reported an elevation [44]. However, these steady-state measures do not provide information as to the metabolic flux (rates of production and depletion) of the molecule of interest. Real-time parameters of aerobic respiration and glycolysis can be measured in live cells by extracellular flux assays, which measure oxygen consumption rates (OCRs) and extracellular acidification rates (ECARs) using intact cells. Published studies of this type both found no significant difference in absolute ATP synthesis rates between the ME/CFS and control cells [41,45]. However, this does not necessarily mean that there is no ATP synthesis defect, since a defect/inefficiency in ATP synthesis could be offset by compensatory homeostatic mechanisms.

The homeostatic regulation of cellular energy metabolism is centered on two stress-sensing protein kinases, AMP-activated protein kinase (AMPK) [46] and target of rapamycin (TOR) [47], which play key, often mutually inhibitory, roles. If their activities are chronically dysregulated by metabolic abnormalities and energy insufficiencies in ME/CFS cells, they may be unable to respond to additional energy demand. This is supported by reports of AMPK in muscle cells from people with ME/CFS being unresponsive to stimulation by contraction-induced ATP depletion [43,48]. Such insensitivity could result from AMPK already being in an activated state in these cells, or to its inhibition by chronically hyperactivated TOR complex 1 (TORC1). Elevated TORC1 activity was recently observed in ME/CFS cells (lymphoblasts) and this was accompanied by inefficient mitochondrial ATP synthesis and abnormally high and presumably compensatory expression of mitochondrial proteins [41]. Elevated expression of mitochondrial proteins has also been found in other studies of patient saliva, lymphocytes, and platelets [41,49-51]. Furthermore, reduced creatine kinase (CK) levels in the serum of people with ME/CFS may suggest reduced cellular CK presence [15], which could contribute to inefficient ATP synthesis given the enzyme's roles in ATP homeostasis [52]. Despite the breadth of sample types tested that suggest dysregulated energy metabolism (serum, urine, feces, muscle, B cells, lymphoblasts), it remains to be directly demonstrated that the perturbation of the associated stress-sensing pathways is systemic and this should be an area of future investigation. 
As noted above, glycolytic catabolism of glucose is a major supplier of acetyl coenzyme A (CoA) to the TCA cycle, and this can be assayed in intact cells by measuring the rate of acidification of the medium by cells provided with glucose as a substrate. This has been reported recently using natural killer (NK) cells from a small sample of six patients and six healthy controls [53]. Although the authors found no differences in aerobic respiration rates, they did observe a reduced glycolytic reserve in the ME/CFS cells. The glycolytic reserve is a measure of the excess capacity of glycolysis to meet cellular ATP demands when mitochondrial ATP synthesis by oxidative phosphorylation is inhibited. This small study reported individual $\mathrm{O}_{2}$ consumption and extracellular acidification rates that were either negative or very small positive values, placing them at the threshold of reliable detection. This caveat also applies to heterogeneous peripheral blood mononuclear cell (PBMC) populations, which are commonly used for extracellular flux respirometry and have been previously employed in ME/CFS work [45]. This difficulty arises because peripheral blood lymphocytes are metabolically quiescent [54] and this not only makes metabolic rate assays technically difficult, but it may obscure differences in metabolism that would be apparent in actively metabolizing cells.

\subsection{A Shift Towards Lipid Metabolism}

The TCA cycle can also be provided with acetyl CoA produced by fatty acid beta-oxidation when glucose-derived sources are insufficient [55]. If the provision of substrate to the TCA cycle is indeed deficient in ME/CFS as previously suggested [31,39,40], a role for the compensatory elevation of fatty acid metabolism could be implicated in the disorder [41]. Fatty acid synthesis and beta-oxidation are regulated by both AMPK [56] and TORC1 [57]. AMPK promotes fatty acid beta-oxidation when activated by elevated ATP demand and promotes fatty acid biosynthesis when inactive, while TORC1 exerts the opposite effects. AMPK and TORC1 regulate each other in a complex reciprocal feedback network [58], so that it is also possible for scenarios to arise where both are simultaneously activated [59]. This raises the question: If both AMPK $[43,48]$ and TORC1 [41] activities are elevated in ME/CFS cells, would we expect the rates of fatty acid catabolism to be increased or decreased? An answer may be found within the specific mechanisms of regulatory action of these pathways in lipid homeostasis. Activation of TORC1 promotes fatty acid biosynthesis by elevating the expression of gene products including acetyl-CoA carboxylase (ACC) through the upregulation of transcription factors Sterol Regulatory Element Binding Proteins 1 and 2 (SREBP-1 and SREBP-2) [60]. ACC activity results in an accumulation of malonyl CoA, which is a potent inhibitor of the mitochondrial import of fatty acids for beta oxidation. ACC, however, is a primary regulatory target of AMPK and is inactivated by phosphorylation when AMPK is activated [61]. In this way, the concurrent activation of AMPK and TORC1, if it does indeed occur in ME/CFS cells, may allow AMPK to constrain the effects of TORC1's upregulation of lipid-biosynthesis and downregulation of beta-oxidation. At the same time, both AMPK and TORC1 directly or indirectly induce the expression of diverse mitochondrial proteins, including those involved in fatty acid beta oxidation. The combined effects could be a steady state in which the cells have increased their use of beta oxidation relative to glycolysis as a supplier of acetyl CoA to the TCA cycle. Fatty acid oxidation is normally upregulated as a supplementary energy pathway during fasting or exercise as a response to reduced blood glucose concentration [62]. An increased reliance on fatty acid oxidation, even at rest, may therefore also contribute to the inability for people with ME/CFS to meet the elevated energy demands imposed by exertion. Such a switch to lipid oxidation can be mediated by elevated inflammation [63] and in combination with the pathological inflammation seen in patients [64] could be evidence of a pathological interaction between inflammation and metabolism in ME/CFS. 


\section{Disturbed Immunity, Signaling, and Inflammatory Pathways}

\subsection{NK Cells}

The function of the immune system has been a focus of ME/CFS research for many years. Evidence for immune dysfunction in ME/CFS has largely been sought through study of NK cells, which are cytotoxic immune cells with roles in both the innate and adaptive immune responses. Multiple groups have reported reduced NK cell cytotoxicity or numbers [65-69] combined with concordant alterations to functional surface markers [70-72]. Conversely, other groups have reported increased cytotoxicity in combination with alterations to functional surface markers. For example, perforin, a glycoprotein used as a functional indicator of NK cell cytotoxicity due to its roles in NK cell mediated lysis [73,74], has been reported as upregulated [71], downregulated [65], or, along with every other assessed phenotypic parameter, unaltered in people with ME/CFS [75]. A recent, rigorous large-scale biobank study also found no significant differences in NK cell numbers, subtype composition, or assessed functional parameters [76]. In summation, NK research remains an area of active interest, but in light of conflicting findings, the role of NK cells in the disorder is still not well understood.

\subsection{Calcium Signaling}

Calcium signaling is crucial to immune cell function [77] and is tied to the mitochondria and endoplasmic reticulum as hubs of regulatory control and calcium storage [78]. Therefore, a disturbance to calcium signaling could contribute to pathological outcomes involving immune system or bioenergetic dysfunction, both of which have been implicated in ME/CFS. In addition to the previous evidence of altered surface proteins on NK cells from ME/CFS patients, a reduction in the expression of transient receptor potential melastatin 3 (TRPM3) calcium ion channels [79] has been reported in a subpopulation of ME/CFS NK cells [80-82]. The reason for the reduced expression of TRPM3 in these cells is unknown, but in other cell types, expression of TRPM3 is repressed by the activity of microRNA-204 (miR-204), encoded by intron 6 of the TRPM3 gene [83]. However, miR-204 is not amongst the microRNAs whose expression is reportedly altered in ME/CFS patients [84].

Reduced expression of TRPM3 receptors would be expected to cause a reduction in $\mathrm{Ca}^{2+}$ responses to pregnenolone sulfate (PregS), a specific activating ligand for TRPM3 channels. However, the opposite was observed when $\mathrm{Ca}^{2+}$ levels were assayed by flow cytometry using Indo1, a $\mathrm{Ca}^{2+}$-sensitive fluorescent dye in the TRPM3-depleted NK cells [80]. Subsequent studies using whole cell patch clamping, however, have reported a loss of PregS-stimulated $\mathrm{Ca}^{2+}$ responses [81,82].

\subsection{Links to Mitochondrial Dysfunction}

Cytosolic $\mathrm{Ca}^{2+}$ is a key element in the cell's extensive homeostatic networks, such that $\mathrm{Ca}^{2+}$ signals are regulated by and play regulatory roles in multiple processes in cells, including mitochondrial respiratory activity [85] as well as mitochondrial protein import [86] and the ion transport activity of TRPM3 itself [87], both of which are activated by $\mathrm{Ca}^{2+}$-calmodulin. The mitochondria serve as both a source and a sink for cytosolic $\mathrm{Ca}^{2+}$ and the mitochondria interact closely with the endoplasmic reticulum at sites that mediate the exchange of lipids and $\mathrm{Ca}^{2+}$ signals [88]. The mitochondria thus form a hub of interaction between $\mathrm{Ca}^{2+}$ and other molecular signals that regulate mitochondrial function, such as AMPK and TORC1 activity. In NK cells specifically, where the calcium-signaling defect has been reported, TORC1 activity is required for both effector function and cytokine production [89-91] and it has been suggested that the development of NK cell antiviral memory is influenced by mitochondrial function [92]. The reports of altered NK effector function in ME/CFS could therefore also be related to abnormal mitochondrial function and TOR signaling. Disrupted intracellular signaling and mitochondrial function in ME/CFS have also been previously linked through myriad other pathways provoked by immune-inflammation and oxidative stress [93]. 


\subsection{Inflammation}

Chronic system-wide inflammation is thought to be central to ME/CFS in the clinical setting as it is associated with symptom severity [64], but the evidence demonstrating a role for specific pro-inflammatory cytokines is inconsistent. While there are indeed reports of the elevation of various pro-inflammatory cytokines in ME/CFS [33,71,94-99], which would tie in with the chronic inflammation in the clinical setting, these findings contrast with reports of reduced expression of pro-inflammatory agents, such as interleukin- 8 or transforming growth factor-beta1 [100,101]. Consequently, evidence for the specific directional shift of individual cytokines has been previously summarized as largely inconsistent [102]. Despite these issues, cytokine expression has been previously associated with $\mathrm{ME} / \mathrm{CFS}$ disease duration and may have value in aiding the stratification of patient cohorts [33,94]. One group has shown that a cohort of ME/CFS patients with leaky gut syndrome as a comorbidity may undergo significant symptom remission when the IgM and IgA immune responses are attenuated by treatment with anti-inflammatory and antioxidant medications [103,104]. This finding has contributed towards the potential link between gut hyperpermeability and inflammation in ME/CFS. Therefore, it is likely that dysregulated chronic inflammatory action by the immune system is an aspect of ME/CFS, despite inconsistent reports.

\subsection{Autoimmunity}

Autoimmunity in the condition is an area that remains little researched, and has been most recently summarized and presented as a hypothetical model for ME/CFS, with some ties to gut dysbiosis and aberrant metabolism [105]. Other autoimmune models for ME/CFS have been previously based on rituximab's role in B cell depletion as a possible therapeutic based on the promising outcomes of earlier studies [106,107]. This would be concordant with other reports of elevated naïve and transitional B cells in patients, which may suggest autoimmune tendencies [108]. However, a role for such B cell-mediated autoimmunity in the disorder is now challenged by the negative outcome of the more recent rituximab phase III clinical trial [109], which refutes the previous rituximab work. This may also indicate that autoimmunity only applies as a key pathomechanism in a small subset of patients who respond positively to rituximab treatment [110]. Other direct lines of evidence for autoimmune behavior in the disorder come from elevated autoantibody levels in sera [111], supported by the improvement of symptoms following autoantibody removal treatment [112], and abnormal IgM immune recognition of both microbial and human heat shock protein 60 in a subset of patients [113] or against phosphatidylinositol [114], despite the absence of an infective pathogen in each case.

\section{Implications of Altered Gut Microbiota and Physiology}

A disturbed gut microbiota [12,115-121] has been proposed to play a role in ME/CFS. This is accompanied by physiological gut abnormalities, such as impaired motility [122], elevated intestinal wall permeability $[103,104,123,124]$, and IBS comorbidity $[31,125,126]$, which has been proposed to comprise part of a ME/CFS subtype [30]. The implications of these disturbances could be far-reaching, since the intestinal microbiota both regulates $[127,128]$ and is regulated by $[129,130]$ the immune system. Additionally, many studies have demonstrated a link between the gut microbiota and host mitochondrial function or metabolism, with disturbances in one resulting in subsequent dysfunction in the other [131-136].

\subsection{The Gut Microbiota and Metabolism}

People with ME/CFS have been reported to present with gut microbiota disturbances and either metabolite variation $[31,118]$ or mitochondrial dysfunction [116] and the two conditions could be linked. Sheedy et al. observed elevated Gram positive intestinal bacteria, which produce lactic acid that may lower the gut $\mathrm{pH}$ and lead to elevated gut permeability [137]. Furthermore, the translocation of these enteric lactic acid products into the bloodstream could contribute to the elevated lactate reported 
in the cerebrospinal fluid of ME/CFS patients [138-140] and in the blood of a subgroup of patients [141]. This contrasts with reports of reduced blood lactate as measured by H-NMR metabolomics [39], which suggests that lactic acidosis may only affect a subgroup of patients. If IBS comorbidity accompanied by gut dysbiosis and hyperpermeability is indeed a subtype of ME/CFS, the translocation of lactic acid produced by abnormally enriched Gram positive enteric bacteria in the affected individuals, rather than excessive production by the host metabolism, could explain this inconsistency.

\subsection{Pathological Interactions between Gut Hyperpermeability and the Mitochondria}

Broader implications for the immune system and mitochondrial function may come from reports of increased translocation of immunogenic bacterial secretions from the gut into the bloodstream, which in ME/CFS may be mediated by intestinal wall hyperpermeability in patients affected with IBS [104,142]. For example, the generation of excess free radicals, which occurs in the mitochondria [143], has been proposed to form part of a microbial defense mechanism [144-146], with enteric species, such as Escherichia coli, highly susceptible to the bactericidal properties of free radical derived reactive nitrogen species (RNS) [147]. Excess free radical generation not only results in the formation of RNS but also reactive oxygen species (ROS), whose production may be elevated in ME/CFS given the many reports of elevated oxidative stress in the disorder [148-153]. Therefore, excessive free radical generation as such an antimicrobial response to circulating antagonists of enteric origin could provide one explanation for the reports of elevated oxidative stress in the disorder. Such a response may indeed be elicited by the ordinarily commensal Gram negative bacteria E. coli, which, while also known to target the mitochondria by the secretion of other toxins [154,155], secretes immunogenic lipopolysaccharide (LPS). This endotoxin secretion is normally suppressed by the host microbiota at large [131], however, the composition of the host microbiota is reportedly altered in cases of ME/CFS [12,115-121]. Such a disturbance to the normal LPS secretion-suppressing host microbiota in ME/CFS and the presence of gut hyperpermeability may therefore not only lead to the synergistic amplification of bacterial toxin translocation into the blood and the consequent activation of inflammatory pathways [104,142], but may also expose body-wide mitochondria to circulating virulent factors produced by Gram negative antagonists, such as E.coli. This is supported by the increase in E. coli gut colonization reported in cases of IBS [156], which, again, can be an ME/CFS comorbidity.

\subsection{The Gut-Brain Axis: Autonomic and Hormonal Dysregulation}

Physiological stress, considered one predisposing factor for ME/CFS [157], has been suggested to play a role in modifying the gut microbiota in such a way that would reduce the numbers of Bifidobacterium and Lactobacillus, two genera responsible for the suppression of LPS-secreting commensal bacteria and has been implicated in this way in ME/CFS [158,159]. While the translocation of immunogenic LPS into the bloodstream is generally associated with body-wide inflammation [160,161], it may also lead to the elevation of proinflammatory elements and the stress hormone cortisol in the brain [162]. The transduction of immunogenic pathogen signals is but one aspect of the gut-brain axis, so it is pertinent to address the potential for broader gut-brain driven [163,164] or autonomic nervous dysregulation that may play a part in the disorder. Indeed, there is some evidence to support such dysregulation associated with vasomotor abnormalities [165] or mitochondrial Coenzyme Q10 deficiency associated with cardiovascular lesions [166]. There are relevant, respectively, to the ME/CFS comorbidity POTS, which likely involves vasomotor dysfunction [167], or to the cardinal symptom of chronic fatigue. Further, the linkage of cortisol-driven stress responses to the gut through the hypothalamic-pituitary-adrenal (HPA) axis [168] could be dysfunctional in ME/CFS due to the hypocortisolism previously suggested to play a role in the condition $[169,170]$. This possibility could weave another perturbed regulatory loop into the system, which may aid in perpetuating an altered homeostasis. This has been previously reviewed at length [171]. 


\section{Multi-System Pathological Interactions}

\subsection{Exposure to Stressors and the Theoretical Homeostatic Perpetuation of a Disease State}

The reported disturbances to ME/CFS metabolism have been linked to chronic activation of emergency cell survival mechanisms to cope with adverse conditions [7]. These adverse conditions could include energy stress, inflammation, HPA axis dysregulation, or pathogen exposure. They elicit a conserved homeostatic cell danger response [172] that could result in the cell shifting to an alternative resting steady state and contribute to ME/CFS pathology [34]. An alternative explanation would involve chronic ongoing exposure of cells to a causative insult. However, chronic pathogen exposure as the precipitating factor for such a response in ME/CFS seems unlikely, as theories of viral persistence have been thoroughly investigated and the evidence for chronic viral infection in ME/CFS is inconsistent [173].

Another feature of ME/CFS is the characteristic symptom heterogeneity. Patient histories suggest that the initial insult eliciting the shift to the ME/CFS state differs between individuals and so may dysregulate the underlying cellular stress signaling pathways in different ways. This could contribute to inconsistencies between various studies and highlights the need for sensitive diagnostics and patient stratification into recognizably different categories.

No matter the initial insult, each of the aforementioned possibilities can involve the interaction between chronic inflammation and immunological and mitochondrial dysfunction $[99,174,175]$. This is similar to theories previously presented by others pertaining to dysregulated homeostatic feedback loops [34]. Faced with a new challenge, such as the re-emergence of a dormant pathogen, over-exertion, or other stress depending on the tolerance of the individual, the affected pathways could again be perturbed, triggering a molecular cascade during bouts of PEM. In some patients, this may mimic the response to a recurrent infection regardless of whether the new trigger is pathogen-driven. Symptom flare-ups characteristic of ME/CFS may therefore result from antagonization of just one of the underlying nodes of a multi-system pathological web and a symptomatic body-wide cascade ensues.

For example, the elevated oxidative stress reported in the disorder [148-153] may be entangled with perturbed immune-inflammatory pathways [175-178], gut inflammation [158], and dysfunctional mitochondria. This may be exacerbated by other disturbances, such as the reported reduction in CK levels [15], which can lead to the absence of CK-mediated ROS suppression [179]. This raises the possibility of a vicious cycle of immunodysregulation and gut dysbiosis accompanied by poor physiological gut function [122] that contribute to the perpetuation of a chronic bowel disease state. Such an altered state could interact with the previously suggested HPA dysregulation [34] and contribute to the perpetuation of an alternative resting homeostasis.

\subsection{Identifying Underlying Mechanisms}

The earlier sections of this review have discussed the evidence for dysregulated biological mechanisms in ME/CFS patients at the molecular, cellular, tissue, organ, and whole body levels. These changes are summarized in Table 1 and together provide insights into potential underlying disease mechanisms.

Based on current biomedical literature, perturbations to the various systems listed in Table 1 are implicated in the underlying pathological mechanisms in ME/CFS. These phenomena are correlated clinically in that they appear in people with the disorder. However, the causal links between them are unknown and cannot be discerned purely on the basis of clinical correlation. There are many scenarios where more than one of the affected systems may exert pathological effects on another and vice versa. This complex and often reciprocal regulatory cross-talk between systems makes it difficult to distinguish cause from effect, so there is great need for the potential causal relationships to be addressed directly using appropriate experimental models. 
Table 1. Brief summary of relevant reports contributing towards the biomedical basis of ME/CFS.

\begin{tabular}{|c|c|}
\hline Area of Study & Brief Summary of Key Reports in ME/CFS \\
\hline Metabolomics & $\begin{array}{l}\text { - } \quad \text { Multiple reports of disturbed amino acid metabolism [6,38-40,180]. } \\
\text { Dysregulated lipid metabolism }[7,13,31,39] \text {, possible glycolysis } \\
\text { impairment [39], possible PDH impairment [40], urea cycle } \\
\text { dysregulation [6,38]. } \\
\text { - Overall: TCA cycle substrate provision deficiency and reliance on } \\
\text { alternative fuel sources. }\end{array}$ \\
\hline Mitochondrial function & $\begin{array}{l}\text { - } \quad \text { Reduced [9] vs. elevated steady-state ATP levels }[42,44,48] \text { but } \\
\text { resting ATP synthesis rates are normal }[41,45] \text {. } \\
\text { - Complex V inefficient and compensated for by upregulation of } \\
\text { supporting pathways [41]. }\end{array}$ \\
\hline Muscle activity & $\begin{array}{l}\text { - Unresponsive AMPK and reduced glucose }[43,48,141] \text { and oxygen } \\
\text { uptake [181]. }\end{array}$ \\
\hline Natural killer cells & - Overall inconsistent evidence—role mostly unknown [65-72]. \\
\hline Calcium signaling & - $\quad$ Evidence for impaired TRPM3 function $[81,82]$. \\
\hline Inflammation and cytokines & $\begin{array}{l}\text { - Inconsistent molecular evidence }[102,182] \text {, yet is likely to play a } \\
\text { role based on clinical presentation and the many reported } \\
\text { disturbances in related systems. }\end{array}$ \\
\hline Autoimmunity & $\begin{array}{l}\text { - Little researched, but proposed to form a subtype comorbid with } \\
\text { IBS [114]. } \\
\text { Role for B cell-mediated autoimmunity challenged by negative } \\
\text { outcome of rituximab trial }[106,109,110] \text {. }\end{array}$ \\
\hline B cells & $\begin{array}{l}\text { - Linked to mitochondrial disturbances, subset proportions may } \\
\text { vary }[41,45,183] \text {. }\end{array}$ \\
\hline Gut microbiota and physiology & $\begin{array}{l}\text { - Widely reported disturbances to the gut microbiota } \\
{[12,103,115-117,119,120,184] \text { and gut hyperpermeability }} \\
{[103,123,124] \text {. }}\end{array}$ \\
\hline $\begin{array}{l}\text { Autonomic and hormonal } \\
\text { dysregulation }\end{array}$ & $\begin{array}{l}\text { - Vasomotor abnormalities }[165,185], \text { hypocortisolism }[169,170] \text {, } \\
\text { broad HPA axis disturbance }[186,187] \text {. }\end{array}$ \\
\hline
\end{tabular}

For example, the potential impact of gut hyperpermeability on body-wide mitochondrial function has been outlined in Section 4.2. However, the reverse may also take place. The differentiation, proliferation, and function of intestinal epithelial cells is known to depend upon normal mitochondrial function, with mitochondrial dysfunction resulting in subsequent hyperpermeability of the intestinal wall [188-190]. Therefore, it is impossible to distinguish cause from effect in this case with correlations alone. Similarly, changes in metabolite levels in ME/CFS have been associated with both IBS comorbidity [31] and alterations to intestinal flora composition [118]. However, it has not been experimentally shown whether the IBS is caused by host metabolic dysfunction or irregular metabolite production and excretion by an altered gut microbiota, or if the gut microflora and metabolic abnormalities are caused by the IBS.

The influence of the mitochondria upon the function of the immune system has similar implications. The mitochondria can partake in activation or suppression of inflammation indirectly by regulating autophagy, which in turn bears downstream regulatory consequences for the activation of inflammation [191]. Mitochondria also regulate elements of the innate immune system by the release of immunogenic ligands [178] and are important for immune cell effector function due to their classical 
roles in energy production and metabolism. Furthermore, immunological dysfunction is common in conditions which are primarily mitochondrial diseases [192]. This is an important consideration with regard to the gut microbiota since it, in turn, influences and is influenced by the function of the immune system and $[128,163,193,194]$ immune cell population composition [195]. Therefore, changes to any one of the mitochondria, immune system, or gut may dysregulate the others, again emphasizing the importance of future research addressing cause-effect relationships.

\section{Conclusions}

$\mathrm{ME} / \mathrm{CFS}$ is a heterogeneous condition that may encompass scenarios where uncertain, and possibly varying, underlying insults trigger body-wide molecular and cellular perturbations perpetuated by an alternative stable homeostatic states. Diagnostic advancement and the development of tools which objectively and accurately phenotype patients is therefore paramount for the development of mechanistic insight and effective therapeutics.

It is likely that the inflammation and immune dysfunction classically studied in ME/CFS are entangled with dysfunctional energetics, gut health, or autonomic and adrenal dysregulation. The evidence for metabolic and mitochondrial dysfunction indicates inefficient respiration, impaired provision of TCA cycle substrate, and metabolic shifts towards the utilization of alternative metabolites. Immune effector cell dysfunction, chronic inflammation, defective signaling, and elevated oxidative stress may interact with not only the dysfunctional energetics but also with abnormal gut physiology and microbiota composition. These effects on the gut may also tie back to mitochondrial function and vice versa. The reciprocal interactions between these affected systems and the varied clinical presentation of relevant symptoms between individuals make it difficult to postulate cause-effect relationships with confidence. Furthermore, while disturbances to this range of interconnected systems across the body have been demonstrated, in some cases concurrently, this body of research has historically relied upon correlations, which creates the urgent need for research utilizing direct experimental investigation of cause-effect relationships.

Author Contributions: D.M., writing—original draft preparation and editing; S.J.A. and P.R.F., writing一review and editing.

Funding: D.M. was the recipient of a La Trobe University Postgraduate Scholarship and Australian Government Research Training Program Fees Offset. This work was supported by generous patient donations and grants from the Judith Jane Mason \& Harold Stannett Williams Memorial Foundation (Grant IDs: MAS2016F063, MAS2018F00026) and the McCusker Charitable Foundation.

Conflicts of Interest: The authors declare no conflict of interest.

\section{References}

1. Sharpe, M.C.; Archard, L.C.; Banatvala, J.E.; Borysiewicz, L.K.; Clare, A.W.; David, A.; Edwards, R.H.; Hawton, K.E.; Lambert, H.P.; Lane, R.J.; et al. A report-Chronic fatigue syndrome: Guidelines for research. J. R. Soc. Med. 1991, 84, 118-121. [CrossRef] [PubMed]

2. Fukuda, K.; Straus, S.E.; Hickie, I.; Sharpe, M.C.; Dobbins, J.G.; Komaroff, A. The chronic fatigue syndrome: A comprehensive approach to its definition and study. International Chronic Fatigue Syndrome Study Group. Ann. Intern. Med. 1994, 121, 953-959. [CrossRef] [PubMed]

3. Carruthers, B.M.; Jain, A.K.; De Meirleir, K.L.; Peterson, D.L.; Klimas, N.G.; Lerner, A.M.; Bested, A.C.; Flor-Henry, P.; Joshi, P.; Powles, A.C.; et al. Myalgic Encephalomyelitis/Chronic Fatigue Syndrome: Clinical Working Case Definition, Diagnostic and Treatment Protocols. J. Chron. Fatigue Syndr. 2003, 11, 7-36. [CrossRef]

4. Carruthers, B.M.; van de Sande, M.I.; De Meirleir, K.L.; Klimas, N.G.; Broderick, G.; Mitchell, T.; Staines, D.; Powles, A.C.; Speight, N.; Vallings, R.; et al. Myalgic encephalomyelitis: International Consensus Criteria. J. Intern. Med. 2011, 270, 327-338. [CrossRef] [PubMed] 
5. Lidbury, B.A.; Kita, B.; Lewis, D.P.; Hayward, S.; Ludlow, H.; Hedger, M.P.; de Kretser, D.M. Activin B is a novel biomarker for chronic fatigue syndrome/myalgic encephalomyelitis (CFS/ME) diagnosis: A cross sectional study. J. Transl. Med. 2017, 15, 60. [CrossRef] [PubMed]

6. Yamano, E.; Sugimoto, M.; Hirayama, A.; Kume, S.; Yamato, M.; Jin, G.; Tajima, S.; Goda, N.; Iwai, K.; Fukuda, S.; et al. Index markers of chronic fatigue syndrome with dysfunction of TCA and urea cycles. Sci. Rep. 2016, 6, 34990. [CrossRef] [PubMed]

7. Naviaux, R.K.; Naviaux, J.C.; Li, K.; Bright, A.T.; Alaynick, W.A.; Wang, L.; Baxter, A.; Nathan, N.; Anderson, W.; Gordon, E. Metabolic features of chronic fatigue syndrome. Proc. Natl. Acad. Sci. USA 2016, 113, E5472-E5480. [CrossRef] [PubMed]

8. Brenu, E.W.; Ashton, K.J.; van Driel, M.; Staines, D.R.; Peterson, D.; Atkinson, G.M.; Marshall-Gradisnik, S.M. Cytotoxic lymphocyte microRNAs as prospective biomarkers for Chronic Fatigue Syndrome/Myalgic Encephalomyelitis. J. Affect. Disord. 2012, 141, 261-269. [CrossRef]

9. Myhill, S.; Booth, N.E.; McLaren-Howard, J. Chronic fatigue syndrome and mitochondrial dysfunction. Int. J. Clin. Exp. Med. 2009, 2, 1-16.

10. Booth, N.E.; Myhill, S.; McLaren-Howard, J. Mitochondrial dysfunction and the pathophysiology of Myalgic Encephalomyelitis/Chronic Fatigue Syndrome (ME/CFS). Int. J. Clin. Exp. Med. 2012, 5, 208-220.

11. Myhill, S.; Booth, N.E.; McLaren-Howard, J. Targeting mitochondrial dysfunction in the treatment of Myalgic Encephalomyelitis/Chronic Fatigue Syndrome (ME/CFS)-a clinical audit. Int. J. Clin. Exp. Med. 2013, 6, 1-15.

12. Giloteaux, L.; Goodrich, J.K.; Walters, W.A.; Levine, S.M.; Ley, R.E.; Hanson, M.R. Reduced diversity and altered composition of the gut microbiome in individuals with myalgic encephalomyelitis/chronic fatigue syndrome. Microbiome 2016, 4, 30. [CrossRef]

13. Germain, A.; Ruppert, D.; Levine, S.M.; Hanson, M.R. Metabolic profiling of a myalgic encephalomyelitis/chronic fatigue syndrome discovery cohort reveals disturbances in fatty acid and lipid metabolism. Mol. Biosyst. 2017, 13, 371-379. [CrossRef] [PubMed]

14. Esfandyarpour, R.; Kashi, A.; Nemat-Gorgani, M.; Wilhelmy, J.; Davis, R.W. A nanoelectronics-blood-based diagnostic biomarker for myalgic encephalomyelitis/chronic fatigue syndrome (ME/CFS). Proc. Natl. Acad. Sci. USA 2019. [CrossRef]

15. Nacul, L.; de Barros, B.; Kingdon, C.C.; Cliff, J.M.; Clark, T.G.; Mudie, K.; Dockrell, H.M.; Lacerda, E.M. Evidence of Clinical Pathology Abnormalities in People with Myalgic Encephalomyelitis/Chronic Fatigue Syndrome (ME/CFS) from an Analytic Cross-Sectional Study. Diagnostics 2019, 9, 41. [CrossRef]

16. Nacul, L.C.; Mudie, K.; Kingdon, C.C.; Clark, T.G.; Lacerda, E.M. Hand Grip Strength as a Clinical Biomarker for ME/CFS and Disease Severity. Front. Neurol. 2018, 9, 992. [CrossRef]

17. DeLuca, J.; Johnson, S.K.; Ellis, S.P.; Natelson, B.H. Sudden vs gradual onset of chronic fatigue syndrome differentiates individuals on cognitive and psychiatric measures. J. Psychiatr. Res. 1997, 31, 83-90. [CrossRef]

18. Lane, R.J.; Barrett, M.C.; Taylor, D.J.; Kemp, G.J.; Lodi, R. Heterogeneity in chronic fatigue syndrome: Evidence from magnetic resonance spectroscopy of muscle. Neuromuscul. Disord. 1998, 8, 204-209. [CrossRef]

19. Afari, N.; Buchwald, D. Chronic fatigue syndrome: A review. Am. J. Psychiatry 2003, 160, 221-236. [CrossRef]

20. Jason, L.A.; Corradi, K.; Torres-Harding, S.; Taylor, R.R.; King, C. Chronic fatigue syndrome: The need for subtypes. Neuropsychol. Rev. 2005, 15, 29-58. [CrossRef]

21. Morris, G.; Maes, M. Case definitions and diagnostic criteria for Myalgic Encephalomyelitis and Chronic fatigue Syndrome: From clinical-consensus to evidence-based case definitions. Neuroendocrinol. Lett. 2013, 34, 185-199. [PubMed]

22. Hardcastle, S.L.; Brenu, E.W.; Johnston, S.; Nguyen, T.; Huth, T.; Ramos, S.; Staines, D.; Marshall-Gradisnik, S. Longitudinal analysis of immune abnormalities in varying severities of Chronic Fatigue Syndrome/Myalgic Encephalomyelitis patients. J. Transl. Med. 2015, 13, 299. [CrossRef] [PubMed]

23. Maclachlan, L.; Watson, S.; Gallagher, P.; Finkelmeyer, A.; Jason, L.A.; Sunnquist, M.; Newton, J.L. Are current chronic fatigue syndrome criteria diagnosing different disease phenotypes? PLOS ONE 2017, 12, e0186885. [CrossRef] [PubMed]

24. Kerr, J.R.; Petty, R.; Burke, B.; Gough, J.; Fear, D.; Sinclair, L.I.; Mattey, D.L.; Richards, S.C.; Montgomery, J.; Baldwin, D.A.; et al. Gene expression subtypes in patients with chronic fatigue syndrome/myalgic encephalomyelitis. J. Infect. Dis. 2008, 197, 1171-1184. [CrossRef] [PubMed] 
25. Kerr, J.R.; Burke, B.; Petty, R.; Gough, J.; Fear, D.; Mattey, D.L.; Axford, J.S.; Dalgleish, A.G.; Nutt, D.J. Seven genomic subtypes of chronic fatigue syndrome/myalgic encephalomyelitis: A detailed analysis of gene networks and clinical phenotypes. J. Clin. Pathol. 2008, 61, 730-739. [CrossRef] [PubMed]

26. Zhang, L.; Gough, J.; Christmas, D.; Mattey, D.L.; Richards, S.C.; Main, J.; Enlander, D.; Honeybourne, D.; Ayres, J.G.; Nutt, D.J.; et al. Microbial infections in eight genomic subtypes of chronic fatigue syndrome/myalgic encephalomyelitis. J. Clin. Pathol. 2010, 63, 156-164. [CrossRef] [PubMed]

27. Light, K.C.; Agarwal, N.; Iacob, E.; White, A.T.; Kinney, A.Y.; VanHaitsma, T.A.; Aizad, H.; Hughen, R.W.; Bateman, L.; Light, A.R. Differing leukocyte gene expression profiles associated with fatigue in patients with prostate cancer versus chronic fatigue syndrome. Psychoneuroendocrinology 2013, 38, 2983-2995. [CrossRef]

28. De Vega, W.C.; Erdman, L.; Vernon, S.D.; Goldenberg, A.; McGowan, P.O. Integration of DNA methylation \& health scores identifies subtypes in myalgic encephalomyelitis/chronic fatigue syndrome. Epigenomics 2018, 10, 539-557. [CrossRef]

29. Jason, L.A.; Boulton, A.; Porter, N.S.; Jessen, T.; Njoku, M.G.; Friedberg, F. Classification of myalgic encephalomyelitis/chronic fatigue syndrome by types of fatigue. Behav. Med. 2010, 36, 24-31. [CrossRef]

30. Maes, M.; Leunis, J.C.; Geffard, M.; Berk, M. Evidence for the existence of Myalgic Encephalomyelitis/Chronic Fatigue Syndrome (ME/CFS) with and without abdominal discomfort (irritable bowel) syndrome. Neuroendocrinol. Lett. 2014, 35, 445-453.

31. Nagy-Szakal, D.; Barupal, D.K.; Lee, B.; Che, X.; Williams, B.L.; Kahn, E.J.R.; Ukaigwe, J.E.; Bateman, L.; Klimas, N.G.; Komaroff, A.L.; et al. Insights into myalgic encephalomyelitis/chronic fatigue syndrome phenotypes through comprehensive metabolomics. Sci. Rep. 2018, 8, 10056. [CrossRef]

32. Richardson, A.M.; Lewis, D.P.; Kita, B.; Ludlow, H.; Groome, N.P.; Hedger, M.P.; de Kretser, D.M.; Lidbury, B.A. Weighting of orthostatic intolerance time measurements with standing difficulty score stratifies ME/CFS symptom severity and analyte detection. J. Transl. Med. 2018, 16, 97. [CrossRef]

33. Russell, L.; Broderick, G.; Taylor, R.; Fernandes, H.; Harvey, J.; Barnes, Z.; Smylie, A.; Collado, F.; Balbin, E.G.; Katz, B.Z.; et al. Illness progression in chronic fatigue syndrome: A shifting immune baseline. BMC Immunol. 2016, 17, 3. [CrossRef]

34. Craddock, T.J.; Fritsch, P.; Rice, M.A., Jr.; del Rosario, R.M.; Miller, D.B.; Fletcher, M.A.; Klimas, N.G.; Broderick, G. A role for homeostatic drive in the perpetuation of complex chronic illness: Gulf War Illness and chronic fatigue syndrome. PLoS ONE 2014, 9, e84839. [CrossRef]

35. Behan, W.M.; More, I.A.; Behan, P.O. Mitochondrial abnormalities in the postviral fatigue syndrome. Acta Neuropathol. 1991, 83, 61-65. [CrossRef]

36. Barnes, P.R.; Taylor, D.J.; Kemp, G.J.; Radda, G.K. Skeletal muscle bioenergetics in the chronic fatigue syndrome. J. Neurol. Neurosurg. Psychiatry 1993, 56, 679-683. [CrossRef]

37. McCully, K.K.; Natelson, B.H.; Iotti, S.; Sisto, S.; Leigh, J.S., Jr. Reduced oxidative muscle metabolism in chronic fatigue syndrome. Muscle Nerve 1996, 19, 621-625. [CrossRef]

38. Armstrong, C.W.; McGregor, N.R.; Sheedy, J.R.; Buttfield, I.; Butt, H.L.; Gooley, P.R. NMR metabolic profiling of serum identifies amino acid disturbances in chronic fatigue syndrome. Clin. Chim. Acta 2012, 413, 1525-1531. [CrossRef]

39. Armstrong, C.W.; McGregor, N.R.; Lewis, D.; Butt, H.; Gooley, P.R. Metabolic profiling reveals anomalous energy metabolism and oxidative stress pathways in chronic fatigue syndrome patients. Metabolomics 2015, 11, 1626-1639. [CrossRef]

40. Fluge, O.; Mella, O.; Bruland, O.; Risa, K.; Dyrstad, S.E.; Alme, K.; Rekeland, I.G.; Sapkota, D.; Rosland, G.V.; Fossa, A.; et al. Metabolic profiling indicates impaired pyruvate dehydrogenase function in myalgic encephalopathy/chronic fatigue syndrome. JCI Insight 2016, 1, e89376. [CrossRef]

41. Missailidis, D.; Annesley, S.J.; Allan, C.Y.; Sanislav, O.; Lidbury, B.A.; Lewis, D.P.; Fisher, P.R. An isolated Complex V defect and dysregulated mitochondrial function in immortalized lymphocytes from ME/CFS patients. 2019. submitted.

42. Castro-Marrero, J.; Cordero, M.D.; Saez-Francas, N.; Jimenez-Gutierrez, C.; Aguilar-Montilla, F.J.; Aliste, L.; Alegre-Martin, J. Could mitochondrial dysfunction be a differentiating marker between chronic fatigue syndrome and fibromyalgia? Antioxid. Redox Signal. 2013, 19, 1855-1860. [CrossRef] [PubMed]

43. Brown, A.E.; Dibnah, B.; Fisher, E.; Newton, J.L.; Walker, M. Pharmacological activation of AMPK and glucose uptake in cultured human skeletal muscle cells from patients with ME/CFS. Biosci. Rep. 2018, 38. [CrossRef] [PubMed] 
44. Lawson, N.; Hsieh, C.H.; March, D.; Wang, X. Elevated Energy Production in Chronic Fatigue Syndrome Patients. J. Nat. Sci. 2016, 2, e221.

45. Tomas, C.; Brown, A.; Strassheim, V.; Elson, J.L.; Newton, J.; Manning, P. Cellular bioenergetics is impaired in patients with chronic fatigue syndrome. PLoS ONE 2017, 12, e0186802. [CrossRef] [PubMed]

46. Hardie, D.G.; Carling, D. The AMP-activated protein kinase-fuel gauge of the mammalian cell? Eur. J. Biochem. 1997, 246, 259-273. [CrossRef]

47. Ma, X.M.; Blenis, J. Molecular mechanisms of mTOR-mediated translational control. Nat. Rev. Mol. Cell Biol. 2009, 10, 307-318. [CrossRef]

48. Brown, A.E.; Jones, D.E.; Walker, M.; Newton, J.L. Abnormalities of AMPK activation and glucose uptake in cultured skeletal muscle cells from individuals with chronic fatigue syndrome. PLoS ONE 2015, 10, e0122982. [CrossRef]

49. Ciregia, F.; Kollipara, L.; Giusti, L.; Zahedi, R.P.; Giacomelli, C.; Mazzoni, M.R.; Giannaccini, G.; Scarpellini, P.; Urbani, A.; Sickmann, A.; et al. Bottom-up proteomics suggests an association between differential expression of mitochondrial proteins and chronic fatigue syndrome. Transl. Psychiatry 2016, 6, e904. [CrossRef]

50. Kaushik, N.; Fear, D.; Richards, S.C.; McDermott, C.R.; Nuwaysir, E.F.; Kellam, P.; Harrison, T.J.; Wilkinson, R.J.; Tyrrell, D.A.; Holgate, S.T.; et al. Gene expression in peripheral blood mononuclear cells from patients with chronic fatigue syndrome. J. Clin. Pathol. 2005, 58, 826-832. [CrossRef]

51. Vernon, S.D.; Whistler, T.; Cameron, B.; Hickie, I.B.; Reeves, W.C.; Lloyd, A. Preliminary evidence of mitochondrial dysfunction associated with post-infective fatigue after acute infection with Epstein Barr virus. BMC Infect. Dis. 2006, 6, 15. [CrossRef] [PubMed]

52. Wallimann, T.; Wyss, M.; Brdiczka, D.; Nicolay, K.; Eppenberger, H.M. Intracellular compartmentation, structure and function of creatine kinase isoenzymes in tissues with high and fluctuating energy demands: The "phosphocreatine circuit" for cellular energy homeostasis. Biochem. J. 1992, 28, 21-40. [CrossRef] [PubMed]

53. Nguyen, T.; Staines, D.; Johnston, S.; Marshall-Gradisnik, S. Reduced glycolytic reserve in isolated natural killer cells from Myalgic encephalomyelitis/chronic fatigue syndrome patients: A preliminary investigation. Asian Pac. J. Allergy Immunol. 2018. [CrossRef]

54. Gardiner, C.M.; Finlay, D.K. What Fuels Natural Killers? Metabolism and NK Cell Responses. Front. Immunol. 2017, 8, 367. [CrossRef] [PubMed]

55. Abdel-aleem, S.; Nada, M.A.; Sayed-Ahmed, M.; Hendrickson, S.C.; St Louis, J.; Walthall, H.P.; Lowe, J.E. Regulation of fatty acid oxidation by acetyl-CoA generated from glucose utilization in isolated myocytes. J. Mol. Cell. Cardiol. 1996, 28, 825-833. [CrossRef] [PubMed]

56. Hardie, D.G.; Pan, D.A. Regulation of fatty acid synthesis and oxidation by the AMP-activated protein kinase. Biochem. Soc. Trans. 2002, 30, 1064-1070. [CrossRef] [PubMed]

57. Laplante, M.; Sabatini, D.M. mTOR signaling in growth control and disease. Cell 2012, 149, $274-293$. [CrossRef] [PubMed]

58. Hindupur, S.K.; Gonzalez, A.; Hall, M.N. The opposing actions of target of rapamycin and AMP-activated protein kinase in cell growth control. Cold Spring Harb. Perspect. Biol. 2015, 7, a019141. [CrossRef]

59. Dalle Pezze, P.; Ruf, S.; Sonntag, A.G.; Langelaar-Makkinje, M.; Hall, P.; Heberle, A.M.; Razquin Navas, P.; van Eunen, K.; Tolle, R.C.; Schwarz, J.J.; et al. A systems study reveals concurrent activation of AMPK and mTOR by amino acids. Nat. Commun. 2016, 7, 13254. [CrossRef]

60. Horton, J.D.; Shah, N.A.; Warrington, J.A.; Anderson, N.N.; Park, S.W.; Brown, M.S.; Goldstein, J.L. Combined analysis of oligonucleotide microarray data from transgenic and knockout mice identifies direct SREBP target genes. Proc. Natl. Acad. Sci. USA 2003, 100, 12027-12032. [CrossRef]

61. Winder, W.W.; Hardie, D.G. Inactivation of acetyl-CoA carboxylase and activation of AMP-activated protein kinase in muscle during exercise. Am. J. Physiol. 1996, 270, E299-E304. [CrossRef]

62. Bartlett, K.; Eaton, S. Mitochondrial beta-oxidation. Eur. J. Biochem. 2004, 271, 462-469. [CrossRef] [PubMed]

63. Liu, T.F.; Vachharajani, V.T.; Yoza, B.K.; McCall, C.E. NAD+-dependent sirtuin 1 and 6 proteins coordinate a switch from glucose to fatty acid oxidation during the acute inflammatory response. J. Biol. Chem. 2012, 287, 25758-25769. [CrossRef] [PubMed]

64. Komaroff, A.L. Inflammation correlates with symptoms in chronic fatigue syndrome. Proc. Natl. Acad. Sci. USA 2017, 114, 8914-8916. [CrossRef] [PubMed] 
65. Maher, K.J.; Klimas, N.G.; Fletcher, M.A. Chronic fatigue syndrome is associated with diminished intracellular perforin. Clin. Exp. Immunol. 2005, 142, 505-511. [CrossRef]

66. Fletcher, M.A.; Zeng, X.R.; Maher, K.; Levis, S.; Hurwitz, B.; Antoni, M.; Broderick, G.; Klimas, N.G. Biomarkers in chronic fatigue syndrome: Evaluation of natural killer cell function and dipeptidyl peptidase IV/CD26. PLoS ONE 2010, 5, e10817. [CrossRef] [PubMed]

67. Marshall-Gradisnik, S.; Huth, T.; Chacko, A.; Johnston, S.; Smith, P.; Staines, D. Natural killer cells and single nucleotide polymorphisms of specific ion channels and receptor genes in myalgic encephalomyelitis/chronic fatigue syndrome. Appl. Clin. Genet. 2016, 9, 39-47. [CrossRef]

68. Lorusso, L.; Mikhaylova, S.V.; Capelli, E.; Ferrari, D.; Ngonga, G.K.; Ricevuti, G. Immunological aspects of chronic fatigue syndrome. Autoimmun. Rev. 2009, 8, 287-291. [CrossRef]

69. Barker, E.; Fujimura, S.F.; Fadem, M.B.; Landay, A.L.; Levy, J.A. Immunologic abnormalities associated with chronic fatigue syndrome. Clin. Infect. Dis. 1994, 18, S136-S141. [CrossRef]

70. Tirelli, U.; Marotta, G.; Improta, S.; Pinto, A. Immunological abnormalities in patients with chronic fatigue syndrome. Scand. J. Immunol. 1994, 40, 601-608. [CrossRef]

71. Brenu, E.W.; van Driel, M.L.; Staines, D.R.; Ashton, K.J.; Ramos, S.B.; Keane, J.; Klimas, N.G.; Marshall-Gradisnik, S.M. Immunological abnormalities as potential biomarkers in Chronic Fatigue Syndrome/Myalgic Encephalomyelitis. J. Transl. Med. 2011, 9, 81. [CrossRef]

72. Klimas, N.G.; Salvato, F.R.; Morgan, R.; Fletcher, M.A. Immunologic abnormalities in chronic fatigue syndrome. J. Clin. Microbiol. 1990, 28, 1403-1410.

73. Kawasaki, A.; Shinkai, Y.; Kuwana, Y.; Furuya, A.; Iigo, Y.; Hanai, N.; Itoh, S.; Yagita, H.; Okumura, K. Perforin, a pore-forming protein detectable by monoclonal antibodies, is a functional marker for killer cells. Int. Immunol. 1990, 2, 677-684. [CrossRef]

74. Osinska, I.; Popko, K.; Demkow, U. Perforin: An important player in immune response. Cent. Eur. J. Immunol. 2014, 39, 109-115. [CrossRef]

75. Theorell, J.; Bileviciute-Ljungar, I.; Tesi, B.; Schlums, H.; Johnsgaard, M.S.; Asadi-Azarbaijani, B.; Bolle Strand, E.; Bryceson, Y.T. Unperturbed Cytotoxic Lymphocyte Phenotype and Function in Myalgic Encephalomyelitis/Chronic Fatigue Syndrome Patients. Front. Immunol. 2017, 8, 723. [CrossRef]

76. Cliff, J.M.; King, E.C.; Lee, J.S.; Sepulveda, N.; Wolf, A.S.; Kingdon, C.; Bowman, E.; Dockrell, H.M.; Nacul, L.; Lacerda, E.; et al. Cellular Immune Function in Myalgic Encephalomyelitis/Chronic Fatigue Syndrome (ME/CFS). Front. Immunol. 2019, 10, 796. [CrossRef]

77. Vig, M.; Kinet, J.-P. Calcium signalling in immune cells. Nat. Immunol. 2009, 10, 21-27. [CrossRef]

78. Rizzuto, R.; De Stefani, D.; Raffaello, A.; Mammucari, C. Mitochondria as sensors and regulators of calcium signalling. Nat. Rev. Mol. Cell Biol. 2012, 13, 566-578. [CrossRef]

79. Grimm, C.; Kraft, R.; Sauerbruch, S.; Schultz, G.; Harteneck, C. Molecular and functional characterization of the melastatin-related cation channel TRPM3. J. Biol. Chem. 2003, 278, 21493-21501. [CrossRef]

80. Nguyen, T.; Johnston, S.; Clarke, L.; Smith, P.; Staines, D.; Marshall-Gradisnik, S. Impaired calcium mobilization in natural killer cells from chronic fatigue syndrome/myalgic encephalomyelitis patients is associated with transient receptor potential melastatin 3 ion channels. Clin. Exp. Immunol. 2017, 187, 284-293. [CrossRef]

81. Cabanas, H.; Muraki, K.; Eaton, N.; Balinas, C.; Staines, D.; Marshall-Gradisnik, S. Loss of Transient Receptor Potential Melastatin 3 ion channel function in natural killer cells from Chronic Fatigue Syndrome/Myalgic Encephalomyelitis patients. Mol. Med. 2018, 24, 44. [CrossRef] [PubMed]

82. Cabanas, H.; Muraki, K.; Balinas, C.; Eaton-Fitch, N.; Staines, D.; Marshall-Gradisnik, S. Validation of impaired Transient Receptor Potential Melastatin 3 ion channel activity in natural killer cells from Chronic Fatigue Syndrome/ Myalgic Encephalomyelitis patients. Mol. Med. 2019, 25, 14. [CrossRef]

83. Cost, N.G.; Czyzyk-Krzeska, M.F. Regulation of autophagy by two products of one gene: TRPM3 and miR-204. Mol. Cell. Oncol. 2015, 2, e1002712. [CrossRef] [PubMed]

84. Almenar-Perez, E.; Sanchez-Fito, T.; Ovejero, T.; Nathanson, L.; Oltra, E. Impact of Polypharmacy on Candidate Biomarker miRNomes for the Diagnosis of Fibromyalgia and Myalgic Encephalomyelitis/Chronic Fatigue Syndrome: Striking Back on Treatments. Pharmaceutics 2019, 11, 126. [CrossRef]

85. Tepikin, A.V. Mitochondrial junctions with cellular organelles: $\mathrm{Ca}^{2+}$ signalling perspective. Pflugers Arch. 2018, 470, 1181-1192. [CrossRef] [PubMed] 
86. Aich, A.; Shaha, C. Novel role of calmodulin in regulating protein transport to mitochondria in a unicellular eukaryote. Mol. Cell. Biol. 2013, 33, 4579-4593. [CrossRef] [PubMed]

87. Przibilla, J.; Dembla, S.; Rizun, O.; Lis, A.; Jung, M.; Oberwinkler, J.; Beck, A.; Philipp, S.E. Ca ${ }^{2+}$-dependent regulation and binding of calmodulin to multiple sites of Transient Receptor Potential Melastatin 3 (TRPM3) ion channels. Cell Calcium 2018, 73, 40-52. [CrossRef] [PubMed]

88. Szymanski, J.; Janikiewicz, J.; Michalska, B.; Patalas-Krawczyk, P.; Perrone, M.; Ziolkowski, W.; Duszynski, J.; Pinton, P.; Dobrzyn, A.; Wieckowski, M.R. Interaction of Mitochondria with the Endoplasmic Reticulum and Plasma Membrane in Calcium Homeostasis, Lipid Trafficking and Mitochondrial Structure. Int. J. Mol. Sci. 2017, 18, 1576. [CrossRef]

89. Donnelly, R.P.; Loftus, R.M.; Keating, S.E.; Liou, K.T.; Biron, C.A.; Gardiner, C.M.; Finlay, D.K. mTORC1-dependent metabolic reprogramming is a prerequisite for NK cell effector function. J. Immunol. 2014, 193, 4477-4484. [CrossRef]

90. Viel, S.; Marcais, A.; Guimaraes, F.S.; Loftus, R.; Rabilloud, J.; Grau, M.; Degouve, S.; Djebali, S.; Sanlaville, A.; Charrier, E.; et al. TGF-beta inhibits the activation and functions of NK cells by repressing the mTOR pathway. Sci. Signal. 2016, 9, ra19. [CrossRef]

91. Salmond, R.J.; Mirchandani, A.S.; Besnard, A.G.; Bain, C.C.; Thomson, N.C.; Liew, F.Y. IL-33 induces innate lymphoid cell-mediated airway inflammation by activating mammalian target of rapamycin. J. Allergy Clin. Immunol. 2012, 130, 1159-1166.e1156. [CrossRef] [PubMed]

92. Wagner, J.A.; Fehniger, T.A. Memory NK Cells Take Out the (Mitochondrial) Garbage. Immunity 2015, 43, 218-220. [CrossRef] [PubMed]

93. Morris, G.; Maes, M. Oxidative and Nitrosative Stress and Immune-Inflammatory Pathways in Patients with Myalgic Encephalomyelitis (ME)/Chronic Fatigue Syndrome (CFS). Curr. Neuropharmacol. 2014, 12, 168-185. [CrossRef] [PubMed]

94. Hornig, M.; Montoya, J.G.; Klimas, N.G.; Levine, S.; Felsenstein, D.; Bateman, L.; Peterson, D.L.; Gottschalk, C.G.; Schultz, A.F.; Che, X.; et al. Distinct plasma immune signatures in ME/CFS are present early in the course of illness. Sci. Adv. 2015, 1. [CrossRef] [PubMed]

95. Maes, M.; Twisk, F.N.; Ringel, K. Inflammatory and cell-mediated immune biomarkers in myalgic encephalomyelitis/chronic fatigue syndrome and depression: Inflammatory markers are higher in myalgic encephalomyelitis/chronic fatigue syndrome than in depression. Psychother. Psychosom. 2012, 81, 286-295. [CrossRef] [PubMed]

96. Milrad, S.F.; Hall, D.L.; Jutagir, D.R.; Lattie, E.G.; Ironson, G.H.; Wohlgemuth, W.; Nunez, M.V.; Garcia, L.; Czaja, S.J.; Perdomo, D.M.; et al. Poor sleep quality is associated with greater circulating pro-inflammatory cytokines and severity and frequency of chronic fatigue syndrome/myalgic encephalomyelitis (CFS/ME) symptoms in women. J. NeuroImmunol. 2017, 303, 43-50. [CrossRef] [PubMed]

97. Montoya, J.G.; Holmes, T.H.; Anderson, J.N.; Maecker, H.T.; Rosenberg-Hasson, Y.; Valencia, I.J.; Chu, L.; Younger, J.W.; Tato, C.M.; Davis, M.M. Cytokine signature associated with disease severity in chronic fatigue syndrome patients. Proc. Natl. Acad. Sci. USA 2017, 114, E7150-E7158. [CrossRef] [PubMed]

98. Peterson, D.; Brenu, E.W.; Gottschalk, G.; Ramos, S.; Nguyen, T.; Staines, D.; Marshall-Gradisnik, S. Cytokines in the cerebrospinal fluids of patients with chronic fatigue syndrome/myalgic encephalomyelitis. Mediat. Inflamm. 2015, 2015, 929720. [CrossRef]

99. Maes, M.; Twisk, F.N.; Kubera, M.; Ringel, K. Evidence for inflammation and activation of cell-mediated immunity in Myalgic Encephalomyelitis/Chronic Fatigue Syndrome (ME/CFS): Increased interleukin-1, tumor necrosis factor-alpha, PMN-elastase, lysozyme and neopterin. J. Affect. Disord. 2012, 136, 933-939. [CrossRef]

100. Tomoda, A.; Joudoi, T.; Rabab, E.M.; Matsumoto, T.; Park, T.H.; Miike, T. Cytokine production and modulation: Comparison of patients with chronic fatigue syndrome and normal controls. Psychiatry Res. 2005, 134, 101-104. [CrossRef]

101. Fletcher, M.A.; Zeng, X.R.; Barnes, Z.; Levis, S.; Klimas, N.G. Plasma cytokines in women with chronic fatigue syndrome. J. Transl. Med. 2009, 7, 96. [CrossRef]

102. Mensah, F.K.F.; Bansal, A.S.; Ford, B.; Cambridge, G. Chronic fatigue syndrome and the immune system: Where are we now? Neurophysiol. Clin. 2017, 47, 131-138. [CrossRef] 
103. Maes, M.; Coucke, F.; Leunis, J.C. Normalization of the increased translocation of endotoxin from gram negative enterobacteria (leaky gut) is accompanied by a remission of chronic fatigue syndrome. Neuroendocrinol. Lett. 2007, 28, 739-744.

104. Maes, M.; Leunis, J.C. Normalization of leaky gut in chronic fatigue syndrome (CFS) is accompanied by a clinical improvement: Effects of age, duration of illness and the translocation of LPS from gram-negative bacteria. Neuroendocrinol. Lett. 2008, 29, 902-910.

105. Blomberg, J.; Gottfries, C.G.; Elfaitouri, A.; Rizwan, M.; Rosen, A. Infection Elicited Autoimmunity and Myalgic Encephalomyelitis/Chronic Fatigue Syndrome: An Explanatory Model. Front. Immunol. 2018, 9, 229. [CrossRef]

106. Fluge, O.; Risa, K.; Lunde, S.; Alme, K.; Rekeland, I.G.; Sapkota, D.; Kristoffersen, E.K.; Sorland, K.; Bruland, O.; Dahl, O.; et al. B-Lymphocyte Depletion in Myalgic Encephalopathy/ Chronic Fatigue Syndrome. An Open-Label Phase II Study with Rituximab Maintenance Treatment. PLoS ONE 2015, 10, e0129898. [CrossRef]

107. Fluge, O.; Mella, O. Clinical impact of B-cell depletion with the anti-CD20 antibody rituximab in chronic fatigue syndrome: A preliminary case series. BMC Neurol. 2009, 9, 28. [CrossRef]

108. Bradley, A.S.; Ford, B.; Bansal, A.S. Altered functional B cell subset populations in patients with chronic fatigue syndrome compared to healthy controls. Clin. Exp. Immunol. 2013, 172, 73-80. [CrossRef]

109. Fluge, O.; Rekeland, I.G.; Lien, K.; Thurmer, H.; Borchgrevink, P.C.; Schafer, C.; Sorland, K.; Assmus, J.; Ktoridou-Valen, I.; Herder, I.; et al. B-Lymphocyte Depletion in Patients with Myalgic Encephalomyelitis/Chronic Fatigue Syndrome: A Randomized, Double-Blind, Placebo-Controlled Trial. Ann. Intern. Med. 2019. [CrossRef]

110. Rekeland, I.G.; Fluge, O.; Alme, K.; Risa, K.; Sorland, K.; Mella, O.; de Vries, A.; Schjott, J. Rituximab Serum Concentrations and Anti-Rituximab Antibodies During B-Cell Depletion Therapy for Myalgic Encephalopathy/Chronic Fatigue Syndrome. Clin. Ther. 2018. [CrossRef]

111. Loebel, M.; Grabowski, P.; Heidecke, H.; Bauer, S.; Hanitsch, L.G.; Wittke, K.; Meisel, C.; Reinke, P.; Volk, H.D.; Fluge, O.; et al. Antibodies to beta adrenergic and muscarinic cholinergic receptors in patients with Chronic Fatigue Syndrome. Brain Behav. Immun. 2016, 52, 32-39. [CrossRef]

112. Scheibenbogen, C.; Loebel, M.; Freitag, H.; Krueger, A.; Bauer, S.; Antelmann, M.; Doehner, W.; Scherbakov, N.; Heidecke, H.; Reinke, P.; et al. Immunoadsorption to remove ss2 adrenergic receptor antibodies in Chronic Fatigue Syndrome CFS/ME. PLoS ONE 2018, 13, e0193672. [CrossRef]

113. Elfaitouri, A.; Herrmann, B.; Bolin-Wiener, A.; Wang, Y.; Gottfries, C.G.; Zachrisson, O.; Pipkorn, R.; Ronnblom, L.; Blomberg, J. Epitopes of microbial and human heat shock protein 60 and their recognition in myalgic encephalomyelitis. PLoS ONE 2013, 8, e81155. [CrossRef]

114. Maes, M.; Mihaylova, I.; Leunis, J.C. Increased serum IgM antibodies directed against phosphatidyl inositol $(\mathrm{Pi})$ in chronic fatigue syndrome (CFS) and major depression: Evidence that an IgM-mediated immune response against $\mathrm{Pi}$ is one factor underpinning the comorbidity between both CFS and depression. Neuroendocrinol. Lett. 2007, 28, 861-867.

115. Butt, H.L.; Dunstan, R.; McGregor, N.R.; Roberts, T.K. Bacterial colonosis in patients with persistent fatigue. In Proceedings of the AHMF International Clinical and Scientific Conference, Sydney, Australia, 1-2 December 2001.

116. Sheedy, J.R.; Wettenhall, R.E.; Scanlon, D.; Gooley, P.R.; Lewis, D.P.; McGregor, N.; Stapleton, D.I.; Butt, H.L.; de Meirleir, K.L. Increased d-lactic Acid intestinal bacteria in patients with chronic fatigue syndrome. In Vivo 2009, 23, 621-628.

117. Jackson, M.L.; Butt, H.; Ball, M.; Lewis, D.P.; Bruck, D. Sleep quality and the treatment of intestinal microbiota imbalance in Chronic Fatigue Syndrome: A pilot study. Sleep Sci. 2015, 8, 124-133. [CrossRef]

118. Armstrong, C.W.; McGregor, N.R.; Lewis, D.P.; Butt, H.L.; Gooley, P.R. The association of fecal microbiota and fecal, blood serum and urine metabolites in myalgic encephalomyelitis/chronic fatigue syndrome. Metabolomics 2017, 13, 8. [CrossRef]

119. Fremont, M.; Coomans, D.; Massart, S.; De Meirleir, K. High-throughput $16 \mathrm{~S}$ rRNA gene sequencing reveals alterations of intestinal microbiota in myalgic encephalomyelitis/chronic fatigue syndrome patients. Anaerobe 2013, 22, 50-56. [CrossRef] 
120. Shukla, S.K.; Cook, D.; Meyer, J.; Vernon, S.D.; Le, T.; Clevidence, D.; Robertson, C.E.; Schrodi, S.J.; Yale, S.; Frank, D.N. Changes in Gut and Plasma Microbiome following Exercise Challenge in Myalgic Encephalomyelitis/Chronic Fatigue Syndrome (ME/CFS). PLoS ONE 2015, 10, e0145453. [CrossRef]

121. Rao, A.V.; Bested, A.C.; Beaulne, T.M.; Katzman, M.A.; Iorio, C.; Berardi, J.M.; Logan, A.C. A randomized, double-blind, placebo-controlled pilot study of a probiotic in emotional symptoms of chronic fatigue syndrome. Gut Pathog. 2009, 1, 6. [CrossRef]

122. Burnet, R.B.; Chatterton, B.E. Gastric emptying is slow in chronic fatigue syndrome. BMC Gastroenterol. 2004, 4, 32. [CrossRef]

123. Morris, G.; Berk, M.; Carvalho, A.F.; Caso, J.R.; Sanz, Y.; Maes, M. The Role of Microbiota and Intestinal Permeability in the Pathophysiology of Autoimmune and Neuroimmune Processes with an Emphasis on Inflammatory Bowel Disease Type 1 Diabetes and Chronic Fatigue Syndrome. Curr. Pharm. Des. 2016, 22, 6058-6075. [CrossRef]

124. Maes, M.; Mihaylova, I.; Leunis, J.C. Increased serum IgA and IgM against LPS of enterobacteria in chronic fatigue syndrome (CFS): Indication for the involvement of gram-negative enterobacteria in the etiology of CFS and for the presence of an increased gut-intestinal permeability. J. Affect. Disord. 2007, 99, 237-240. [CrossRef]

125. Aaron, L.A.; Burke, M.M.; Buchwald, D. Overlapping conditions among patients with chronic fatigue syndrome, fibromyalgia, and temporomandibular disorder. Arch. Intern. Med. 2000, 160, 221-227. [CrossRef]

126. Tsai, S.Y.; Chen, H.J.; Lio, C.F.; Kuo, C.F.; Kao, A.C.; Wang, W.S.; Yao, W.C.; Chen, C.; Yang, T.Y. Increased risk of chronic fatigue syndrome in patients with inflammatory bowel disease: A population-based retrospective cohort study. J. Transl. Med. 2019, 17, 55. [CrossRef]

127. Grainger, J.; Daw, R.; Wemyss, K. Systemic instruction of cell-mediated immunity by the intestinal microbiome. F1000Research 2018, 7. [CrossRef]

128. Brown, R.L.; Clarke, T.B. The regulation of host defences to infection by the microbiota. Immunology 2017, 150, 1-6. [CrossRef]

129. Neumann, C.; Blume, J.; Roy, U.; Teh, P.P.; Vasanthakumar, A.; Beller, A.; Liao, Y.; Heinrich, F.; Arenzana, T.L.; Hackney, J.A.; et al. c-Maf-dependent Treg cell control of intestinal TH17 cells and IgA establishes host-microbiota homeostasis. Nat. Immunol. 2019, 20, 471-481. [CrossRef]

130. Nakajima, A.; Vogelzang, A.; Maruya, M.; Miyajima, M.; Murata, M.; Son, A.; Kuwahara, T.; Tsuruyama, T.; Yamada, S.; Matsuura, M.; et al. IgA regulates the composition and metabolic function of gut microbiota by promoting symbiosis between bacteria. J. Exp. Med. 2018, 215, 2019-2034. [CrossRef]

131. Kaliannan, K.; Wang, B.; Li, X.Y.; Kim, K.J.; Kang, J.X. A host-microbiome interaction mediates the opposing effects of omega-6 and omega-3 fatty acids on metabolic endotoxemia. Sci. Rep. 2015, 5, 11276. [CrossRef]

132. Clark, A.; Mach, N. The Crosstalk between the Gut Microbiota and Mitochondria during Exercise. Front. Physiol. 2017, 8, 319. [CrossRef]

133. Bretin, A.; Gewirtz, A.T.; Chassaing, B. Microbiota and metabolism: what's new in 2018? Am. J. Physiol. Endocrinol. Metab 2018, 315, E1-E6. [CrossRef]

134. Janssen, A.W.; Kersten, S. The role of the gut microbiota in metabolic health. FASEB J. 2015, 29, 3111-3123. [CrossRef]

135. Chambers, E.S.; Preston, T.; Frost, G.; Morrison, D.J. Role of Gut Microbiota-Generated Short-Chain Fatty Acids in Metabolic and Cardiovascular Health. Curr. Nutr. Rep. 2018, 7, 198-206. [CrossRef]

136. Saint-Georges-Chaumet, Y.; Edeas, M. Microbiota-mitochondria inter-talk: Consequence for microbiota-host interaction. Pathog. Dis. 2016, 74, ftv096. [CrossRef]

137. Henriksson, A.E.; Tagesson, C.; Uribe, A.; Uvnas-Moberg, K.; Nord, C.E.; Gullberg, R.; Johansson, C. Effects of prostaglandin E2 on disease activity, gastric secretion and intestinal permeability, and morphology in patients with rheumatoid arthritis. Ann. Rheum. Dis. 1988, 47, 620-627. [CrossRef]

138. Mathew, S.J.; Mao, X.; Keegan, K.A.; Levine, S.M.; Smith, E.L.; Heier, L.A.; Otcheretko, V.; Coplan, J.D.; Shungu, D.C. Ventricular cerebrospinal fluid lactate is increased in chronic fatigue syndrome compared with generalized anxiety disorder: An in vivo $3.0 \mathrm{~T}^{1} \mathrm{H}$ MRS imaging study. NMR Biomed. 2009, 22, 251-258. [CrossRef]

139. Murrough, J.W.; Mao, X.; Collins, K.A.; Kelly, C.; Andrade, G.; Nestadt, P.; Levine, S.M.; Mathew, S.J.; Shungu, D.C. Increased ventricular lactate in chronic fatigue syndrome measured by $1 \mathrm{H}$ MRS imaging at 3.0 T. II: Comparison with major depressive disorder. NMR Biomed. 2010, 23, 643-650. [CrossRef] 
140. Shungu, D.C.; Weiduschat, N.; Murrough, J.W.; Mao, X.; Pillemer, S.; Dyke, J.P.; Medow, M.S.; Natelson, B.H.; Stewart, J.M.; Mathew, S.J. Increased ventricular lactate in chronic fatigue syndrome. III. Relationships to cortical glutathione and clinical symptoms implicate oxidative stress in disorder pathophysiology. NMR Biomed. 2012, 25, 1073-1087. [CrossRef]

141. Rutherford, G.; Manning, P.; Newton, J.L. Understanding Muscle Dysfunction in Chronic Fatigue Syndrome. J. Aging Res. 2016, 2016, 2497348. [CrossRef]

142. Maes, M.; Twisk, F.N.; Kubera, M.; Ringel, K.; Leunis, J.C.; Geffard, M. Increased IgA responses to the LPS of commensal bacteria is associated with inflammation and activation of cell-mediated immunity in chronic fatigue syndrome. J. Affect. Disord. 2012, 136, 909-917. [CrossRef] [PubMed]

143. Cadenas, E.; Davies, K.J. Mitochondrial free radical generation, oxidative stress, and aging. Free Radic. Biol. Med. 2000, 29, 222-230. [CrossRef]

144. Naviaux, R.K. Oxidative shielding or oxidative stress? J. Pharmacol. Exp. Ther. 2012, 342, 608-618. [CrossRef] [PubMed]

145. Ghosh, S.; Dai, C.; Brown, K.; Rajendiran, E.; Makarenko, S.; Baker, J.; Ma, C.; Halder, S.; Montero, M.; Ionescu, V.A.; et al. Colonic microbiota alters host susceptibility to infectious colitis by modulating inflammation, redox status, and ion transporter gene expression. Am. J. Physiol. Gastrointest. Liver Physiol. 2011, 301, G39-G49. [CrossRef]

146. Abuaita, B.H.; Schultz, T.L.; O’Riordan, M.X. Mitochondria-Derived Vesicles Deliver Antimicrobial Reactive Oxygen Species to Control Phagosome-Localized Staphylococcus aureus. Cell Host Microbe 2018, 24, 625-636. [CrossRef]

147. Hurst, J.K.; Lymar, S.V. Toxicity of peroxynitrite and related reactive nitrogen species toward Escherichia coli. Chem. Res. Toxicol. 1997, 10, 802-810. [CrossRef]

148. Vecchiet, L.; Montanari, G.; Pizzigallo, E.; Iezzi, S.; de Bigontina, P.; Dragani, L.; Vecchiet, J.; Giamberardino, M.A. Sensory characterization of somatic parietal tissues in humans with chronic fatigue syndrome. Neurosci. Lett. 1996, 208, 117-120. [CrossRef]

149. Vecchiet, J.; Cipollone, F.; Falasca, K.; Mezzetti, A.; Pizzigallo, E.; Bucciarelli, T.; De Laurentis, S.; Affaitati, G.; De Cesare, D.; Giamberardino, M.A. Relationship between musculoskeletal symptoms and blood markers of oxidative stress in patients with chronic fatigue syndrome. Neurosci. Lett. 2003, 335, 151-154. [CrossRef]

150. Kennedy, G.; Spence, V.A.; McLaren, M.; Hill, A.; Underwood, C.; Belch, J.J. Oxidative stress levels are raised in chronic fatigue syndrome and are associated with clinical symptoms. Free Radic. Biol. Med. 2005, 39, 584-589. [CrossRef]

151. Jammes, Y.; Steinberg, J.G.; Mambrini, O.; Bregeon, F.; Delliaux, S. Chronic fatigue syndrome: Assessment of increased oxidative stress and altered muscle excitability in response to incremental exercise. J. Intern. Med. 2005, 257, 299-310. [CrossRef] [PubMed]

152. Jammes, Y.; Steinberg, J.G.; Delliaux, S. Chronic fatigue syndrome: Acute infection and history of physical activity affect resting levels and response to exercise of plasma oxidant/antioxidant status and heat shock proteins. J. Intern. Med. 2012, 272, 74-84. [CrossRef] [PubMed]

153. Polli, A.; Van Oosterwijck, J.; Nijs, J.; Marusic, U.; De Wandele, I.; Paul, L.; Meeus, M.; Moorkens, G.; Lambrecht, L.; Ickmans, K. Relationship Between Exercise-induced Oxidative Stress Changes and Parasympathetic Activity in Chronic Fatigue Syndrome: An Observational Study in Patients and Healthy Subjects. Clin. Ther. 2019. [CrossRef] [PubMed]

154. Papatheodorou, P.; Domanska, G.; Oxle, M.; Mathieu, J.; Selchow, O.; Kenny, B.; Rassow, J. The enteropathogenic Escherichia coli (EPEC) Map effector is imported into the mitochondrial matrix by the TOM/Hsp70 system and alters organelle morphology. Cell. Microbiol. 2006, 8, 677-689. [CrossRef] [PubMed]

155. Crane, J.K.; McNamara, B.P.; Donnenberg, M.S. Role of EspF in host cell death induced by enteropathogenic Escherichia coli. Cell. MicroBiol. 2001, 3, 197-211. [CrossRef] [PubMed]

156. Swidsinski, A.; Ladhoff, A.; Pernthaler, A.; Swidsinski, S.; Loening-Baucke, V.; Ortner, M.; Weber, J.; Hoffmann, U.; Schreiber, S.; Dietel, M.; et al. Mucosal flora in inflammatory bowel disease. Gastroenterology 2002, 122, 44-54. [CrossRef] [PubMed]

157. Nater, U.M.; Maloney, E.; Heim, C.; Reeves, W.C. Cumulative life stress in chronic fatigue syndrome. Psychiatry Res. 2011, 189, 318-320. [CrossRef] [PubMed] 
158. Lakhan, S.E.; Kirchgessner, A. Gut inflammation in chronic fatigue syndrome. Nutr. Metab. $2010,7,79$. [CrossRef] [PubMed]

159. Gaab, J.; Rohleder, N.; Heitz, V.; Engert, V.; Schad, T.; Schurmeyer, T.H.; Ehlert, U. Stress-induced changes in LPS-induced pro-inflammatory cytokine production in chronic fatigue syndrome. Psychoneuroendocrinology 2005, 30, 188-198. [CrossRef] [PubMed]

160. Cani, P.D.; Possemiers, S.; Van de Wiele, T.; Guiot, Y.; Everard, A.; Rottier, O.; Geurts, L.; Naslain, D.; Neyrinck, A.; Lambert, D.M.; et al. Changes in gut microbiota control inflammation in obese mice through a mechanism involving GLP-2-driven improvement of gut permeability. Gut 2009, 58, 1091-1103. [CrossRef] [PubMed]

161. Martich, G.D.; Boujoukos, A.J.; Suffredini, A.F. Response of man to endotoxin. Immunobiology 1993, 187, 403-416. [CrossRef]

162. Nordgreen, J.; Munsterhjelm, C.; Aae, F.; Popova, A.; Boysen, P.; Ranheim, B.; Heinonen, M.; Raszplewicz, J.; Piepponen, P.; Lervik, A.; et al. The effect of lipopolysaccharide (LPS) on inflammatory markers in blood and brain and on Behav. ior in individually-housed pigs. Physiol. Behav. 2018, 195, 98-111. [CrossRef] [PubMed]

163. Carabotti, M.; Scirocco, A.; Maselli, M.A.; Severi, C. The gut-brain axis: Interactions between enteric microbiota, central and enteric nervous systems. Ann. Gastroenterol. 2015, 28, 203-209. [PubMed]

164. Furness, J.B. The enteric nervous system: Normal functions and enteric neuropathies. Neurogastroenterol. Motil. 2008, 20 (Suppl. 1), 32-38. [CrossRef] [PubMed]

165. Barnden, L.R.; Kwiatek, R.; Crouch, B.; Burnet, R.; Del Fante, P. Autonomic correlations with MRI are abnormal in the brainstem vasomotor centre in Chronic Fatigue Syndrome. Neuroimage Clin. 2016, 11, 530-537. [CrossRef] [PubMed]

166. Maes, M.; Mihaylova, I.; Kubera, M.; Uytterhoeven, M.; Vrydags, N.; Bosmans, E. Coenzyme Q10 deficiency in myalgic encephalomyelitis/chronic fatigue syndrome (ME/CFS) is related to fatigue, autonomic and neurocognitive symptoms and is another risk factor explaining the early mortality in ME/CFS due to cardiovascular disorder. NeuroEndocrinol. Lett. 2009, 30, 470-476. [PubMed]

167. Freitas, J.; Santos, R.; Azevedo, E.; Costa, O.; Carvalho, M.; de Freitas, A.F. Reversible sympathetic vasomotor dysfunction in POTS patients. Rev. Port. Cardiol. 2000, 19, 1163-1170. [PubMed]

168. Tsigos, C.; Chrousos, G.P. Hypothalamic-pituitary-adrenal axis, neuroendocrine factors and stress. J. Psychosom. Res. 2002, 53, 865-871. [CrossRef]

169. Tak, L.M.; Cleare, A.J.; Ormel, J.; Manoharan, A.; Kok, I.C.; Wessely, S.; Rosmalen, J.G. Meta-analysis and meta-regression of hypothalamic-pituitary-adrenal axis activity in functional somatic disorders. Biol. Psychol. 2011, 87, 183-194. [CrossRef]

170. Poteliakhoff, A. Adrenocortical activity and some clinical findings in acute and chronic fatigue. J. Psychosom. Res. 1981, 25, 91-95. [CrossRef]

171. Tomas, C.; Newton, J.; Watson, S. A review of hypothalamic-pituitary-adrenal axis function in chronic fatigue syndrome. ISRN Neurosci. 2013, 2013, 784520. [CrossRef]

172. Naviaux, R.K. Metabolic features of the cell danger response. Mitochondrion 2014, 16, 7-17. [CrossRef] [PubMed]

173. Rasa, S.; Nora-Krukle, Z.; Henning, N.; Eliassen, E.; Shikova, E.; Harrer, T.; Scheibenbogen, C.; Murovska, M.; Prusty, B.K.; the European Network on ME/CFS. Chronic viral infections in myalgic encephalomyelitis/chronic fatigue syndrome (ME/CFS). J. Transl. Med. 2018, 16, 268. [CrossRef] [PubMed]

174. Lacourt, T.E.; Vichaya, E.G.; Chiu, G.S.; Dantzer, R.; Heijnen, C.J. The High Costs of Low-Grade Inflammation: Persistent Fatigue as a Consequence of Reduced Cellular-Energy Availability and Non-adaptive Energy Expenditure. Front. Behav. NeuroSci. 2018, 12, 78. [CrossRef] [PubMed]

175. Morris, G.; Maes, M. Mitochondrial dysfunctions in myalgic encephalomyelitis/chronic fatigue syndrome explained by activated immuno-inflammatory, oxidative and nitrosative stress pathways. Metab. Brain Dis. 2014, 29, 19-36. [CrossRef] [PubMed]

176. Meeus, M.; Nijs, J.; Hermans, L.; Goubert, D.; Calders, P. The role of mitochondrial dysfunctions due to oxidative and nitrosative stress in the chronic pain or chronic fatigue syndromes and fibromyalgia patients: Peripheral and central mechanisms as therapeutic targets? Expert Opin. Ther. Targets 2013, 17, 1081-1089. [CrossRef] [PubMed]

177. Van Horssen, J.; van Schaik, P.; Witte, M. Inflammation and mitochondrial dysfunction: A vicious circle in neurodegenerative disorders? Neurosci. Lett. 2017. [CrossRef] [PubMed] 
178. Kolmychkova, K.I.; Zhelankin, A.V.; Karagodin, V.P.; Orekhov, A.N. Mitochondria and inflammation. Patol. Fiziol. Eksp. Ter. 2016, 60, 114-121. [PubMed]

179. Meyer, L.E.; Machado, L.B.; Santiago, A.P.; da-Silva, W.S.; De Felice, F.G.; Holub, O.; Oliveira, M.F.; Galina, A. Mitochondrial creatine kinase activity prevents reactive oxygen species generation: Antioxidant role of mitochondrial kinase-dependent ADP re-cycling activity. J. Biol. Chem. 2006, 281, 37361-37371. [CrossRef]

180. Armstrong, C.W.; McGregor, N.R.; Butt, H.L.; Gooley, P.R. Metabolism in chronic fatigue syndrome. Adv. Clin. Chem. 2014, 66, 121-172.

181. Vermeulen, R.C.; Vermeulen van Eck, I.W. Decreased oxygen extraction during cardiopulmonary exercise test in patients with chronic fatigue syndrome. J. Transl. Med. 2014, 12, 20. [CrossRef]

182. Blundell, S.; Ray, K.K.; Buckland, M.; White, P.D. Chronic fatigue syndrome and circulating cytokines: A systematic review. Brain Behav. Immun. 2015, 50, 186-195. [CrossRef] [PubMed]

183. Mensah, F.F.K.; Armstrong, C.W.; Reddy, V.; Bansal, A.S.; Berkovitz, S.; Leandro, M.J.; Cambridge, G. CD24 Expression and B Cell Maturation Shows a Novel Link with Energy Metabolism: Potential Implications for Patients with Myalgic Encephalomyelitis/Chronic Fatigue Syndrome. Front. Immunol. 2018, 9, 2421. [CrossRef] [PubMed]

184. Mandarano, A.H.; Giloteaux, L.; Keller, B.A.; Levine, S.M.; Hanson, M.R. Eukaryotes in the gut microbiota in myalgic encephalomyelitis/chronic fatigue syndrome. PeerJ 2018, 6, e4282. [CrossRef] [PubMed]

185. Allen, J.; Murray, A.; Di Maria, C.; Newton, J.L. Chronic fatigue syndrome and impaired peripheral pulse characteristics on orthostasis-A new potential diagnostic biomarker. Physiol. Meas. 2012, 33, 231-241. [CrossRef] [PubMed]

186. Demitrack, M.A.; Dale, J.K.; Straus, S.E.; Laue, L.; Listwak, S.J.; Kruesi, M.J.; Chrousos, G.P.; Gold, P.W. Evidence for impaired activation of the hypothalamic-pituitary-adrenal axis in patients with chronic fatigue syndrome. J. Clin. Endocrinol. Metab. 1991, 73, 1224-1234. [CrossRef] [PubMed]

187. Papadopoulos, A.S.; Cleare, A.J. Hypothalamic-pituitary-adrenal axis dysfunction in chronic fatigue syndrome. Nat. Rev. Endocrinol. 2011, 8, 22-32. [CrossRef] [PubMed]

188. Berger, E.; Rath, E.; Yuan, D.; Waldschmitt, N.; Khaloian, S.; Allgauer, M.; Staszewski, O.; Lobner, E.M.; Schottl, T.; Giesbertz, P.; et al. Mitochondrial function controls intestinal epithelial stemness and proliferation. Nat. Commun. 2016, 7, 13171. [CrossRef]

189. Novak, E.A.; Mollen, K.P. Mitochondrial dysfunction in inflammatory bowel disease. Front. Cell Dev. Biol. 2015, 3, 62. [CrossRef]

190. Madsen, K.L.; Yanchar, N.L.; Sigalet, D.L.; Reigel, T.; Fedorak, R.N. FK506 increases permeability in rat intestine by inhibiting mitochondrial function. Gastroenterology 1995, 109, 107-114. [CrossRef]

191. Green, D.R.; Galluzzi, L.; Kroemer, G. Mitochondria and the autophagy-inflammation-cell death axis in organismal aging. Science 2011, 333, 1109-1112. [CrossRef]

192. Walker, M.A.; Volpi, S.; Sims, K.B.; Walter, J.E.; Traggiai, E. Powering the immune system: Mitochondria in immune function and deficiency. J. Immunol. Res. 2014, 2014, 164309. [CrossRef]

193. Belkaid, Y.; Hand, T.W. Role of the microbiota in immunity and inflammation. Cell 2014, 157, $121-141$. [CrossRef]

194. Wu, H.J.; Wu, E. The role of gut microbiota in immune homeostasis and autoimmunity. Gut Microbes 2012, 3, 4-14. [CrossRef]

195. Kamada, N.; Nunez, G. Role of the gut microbiota in the development and function of lymphoid cells. J. Immunol. 2013, 190, 1389-1395. [CrossRef]

(C) 2019 by the authors. Licensee MDPI, Basel, Switzerland. This article is an open access article distributed under the terms and conditions of the Creative Commons Attribution (CC BY) license (http://creativecommons.org/licenses/by/4.0/). 